\title{
Analysis of presurgical uterine artery embolization (PUAE) for very large uterus myomatosus; patient's desire to preserve the uterus; case series and literature review
}

\section{Analyse der präoperativen Uterus-Arterien-Embolisation (PUAE) bei großem Uterus myomatosus und Patientenwunsch nach Uteruserhalt - Fallserie und Literaturübersicht}

Authors

Dirk Schnapauff', Manon Russ², Thomas Kröncke³, Matthias David²

Affiliations

1 Charité Universitätsmedizin Berlin, Campus VirchowKlinikum, Department of Radiology, Berlin, Germany

2 Charité Universitätsmedizin Berlin, Campus VirchowKlinikum, Department of Gynecology, Berlin, Germany

3 Klinikum Augsburg, Department of Diagnostic and Interventional Radiology and Neuroradiology, Augsburg, Bavaria, Germany

Key words

embolization, fibroids, preoperative embolization, fertility

received 19.07.2017

accepted 04.01.2018

Bibliography

DOI https://doi.org/10.1055/s-0044-101555

Published online: 8.3.2018

Fortschr Röntgenstr 2018; 190: 616-622

(c) Georg Thieme Verlag KG, Stuttgart · New York

ISSN 1438-9029

Correspondence

PD Dr. Dirk Schnapauff, EBIR

Charité Universitätsmedizin Berlin, Campus Virchow-

Klinikum, Klinik für Radiologie, Augustenburger Platz 1, 13353 Berlin, Deutschland/Germany

Tel.: ++ 49/30/450657267

Fax: ++ 49/30/4507657267

dirk.schnapauff@charite.de

\section{ABSTRACT}

Purpose Purpose of this paper to present results of a group of 21 consecutive patients who underwent uterine artery embolization (UAE) immediately before myomectomy. Surgical myomectomy can lead to a substantial blood loss in case of large or multiple tumors due to the hypervascularization of the tumors. This may lead to multiple blood transfusion or hysterectomy. In cases were the preservation of the uterus is demanded, pre-operative embolization could reduce the risk of substantial bleeding.
Materials and Methods Between January 2011 and March 2016, 21 patients underwent UAE 24 hours before myomectomy. All patients were asked by questionnaire about post-surgical follow-up, complications, the length of the scar, satisfaction and improvement of symptoms. Data of the operation and embolization were retrospectively assessed.

Results UAE could be performed in all patients without complications. Mean diameter of the largest myoma was $12.7 \pm 3.2 \mathrm{~cm}$, primary preservation of the uterus succeeded in all cases. In none of the cases a perioperative blood transfusion was necessary. One patient underwent hysterectomy in another hospital after primary successful resection, one patient received transfusion of 2 bags of red blood cell concentrate during her stay in hospital.

11 of 21 patients responded to the questionnaire. 10 of 11 had subjective symptom improvement. Mean inability to work was 31 days, the mean self-measured length was $12 \mathrm{~cm}$. 9 of 11 patients would recommend the procedure, one patient was in the second trimester of pregnancy.

Conclusion Preoperative uterine artery embolization facilitates a safe and uterus-preserving myomectomy in patients with very large or multiple fibroids.

\section{Key Points}

- Uterus-preserving myomectomy can be used in cases of large uteri or with multiple fibroids with low amount of blood loss.

- The combination of preoperative embolization and subsequent myomectomy may be a therapeutic option in cases of infertility due to a fibroid-induced uterine deformation.

- Good interdisciplinary cooperation is essential for sustainable results in this complex group of patients.

\section{Citation Format}

- Schnapauff D, Russ M, Kröncke T et al. Analysis of presurgical uterine artery embolization (PUAE) for very large uterus myomatosus; patient's desire to preserve the uterus; case series and literature review. Fortschr Röntgenstr 2018; 190: 616-622 


\section{ZUSAMMENFASSUNG}

Ziel Die operative Myomresektion kann durch die Hypervaskularisation der Tumoren bei großen und/ oder zahlreichen Myomen mit einem erheblichen Blutverlust und daraus folgendem Transfusions- und Hysterektomierisiko verbunden sein. Falls ein Erhalt der Gebärmutter erwünscht ist, könnte die präoperative Embolisation das Blutungs- und Hysterektomierisiko reduzieren. Ziel der vorliegenden Arbeit ist es, die Ergebnisse eines Kollektivs von 21 konsekutiven Patientinnen vorzustellen, die unmittelbar vor operativer Myomresektion eine Uterus-Arterien-Embolisation (UAE) erhielten.

Material und Methoden Zwischen Januar 2011 und März 2016 erhielten insgesamt 21 Patientinnen eine Uterus-Arterien-Embolisation ca. 24 Stunden vor geplanter Myomresektion. Alle Patientinnen wurden per Fragebogen zu spätpostoperativem Verlauf, Komplikationen, Narbenlänge, Zufriedenheit und Beschwerdebesserung nachbefragt. Daten der OP und Embolisation wurden ebenfalls retrospektiv ausgewertet.
Ergebnisse Die UAE konnte bei allen Patientinnen komplikationslos durchgeführt werden. Der mittlere Durchmesser des größten resezierten Myoms betrug 12,7 $\pm 3,2 \mathrm{~cm}$, der Uteruserhalt gelang primär in allen Fällen. In keinem Fall war eine Bluttransfusion perioperativ erforderlich. Eine Patientin erhielt extern 14 Tage nach primärer Resektion eine Hysterektomie aufgrund von vaginalen Blutungen, bei einer Patientin war während des stationären Aufenthaltes eine Transfusion von 2 Erythrozytenkonzentraten erforderlich.

11 von 21 Patientinnen beantworteten den Fragebogen. 10 von 11 Patientinnen gaben eine subjektive Beschwerdebesserung an. Die mittlere Krankschreibungsdauer betrug 31 Tage, die mittlere selbst gemessene Narbenlänge $12 \mathrm{~cm}$. 9 von 11 würden den Eingriff weiterempfehlen, eine Patientin war im II. Trimenon schwanger.

Schlussfolgerung Die präoperative Uterusarterienembolisation ermöglicht eine sichere, uteruserhaltende Myomentfernung bei Patientinnen mit sehr großen oder zahlreichen Myomen.

\section{Background}

Uterine fibroids are the most common benign tumors of the female genital tract [1]. The prevalence of fibroids is highly age-dependent, while they are almost never observed in women under the age of 20 , they are detectable in $33-66 \%$ of women between 45 and 50 years of age [2]. Their size and number can vary greatly. Gennaro Della Rossa et al. have suggested defining myomas larger than $9 \mathrm{~cm}$ or more than $800 \mathrm{~g}$ in weight as "giant" [3].

The quality of life can be severely impacted by fibroid-related symptoms [4, 5], although such symptoms do not necessarily correlate with the size of the myoma. Only symptomatic myomas or those affecting fertility should be treated. The therapy of uterine fibroids is primarily aimed at alleviating symptoms and improving the patient's quality of life. When pursuing uterus-preserving treatment measures, however, the preservation or improvement of fertility must always be included in the therapy decision.

In 2008, Klatsky et al. carried out a systematic review and were able to document an increased risk of abortion, a two-and-a-half times increase in the risk of abnormal fetal presentation and a doubled risk of placental previa in patients with a uterine myomatosus compared to patients without fibroids [6]. Parazzini et al. confirmed these results in 2016 [7].

Surgical removal and hysterectomy are still the most widely used methods of treating myomas. A very large uterine myomatosus (for example extending above navel level) always presents a challenge for the surgeon. Because of the size of the uterus, laparoscopic access is not useful in this case. In addition, there is a risk of heavy bleeding from the myoma wound bed and the risk that the uterus can no longer be preserved or reconstructed $[3,8]$.

Since the initial report of successful treatment of uterine myomas via embolization of uterine arteries [9], uterine artery embolization (UAE) has established itself, especially in developed indus- trialized countries, as part of the spectrum of modern uteruspreserving therapies for myoma-associated disorders.

In recent years, a few working groups have reported on planned preoperative uterine artery embolization (PUAE), particularly with regard to large uterine myomas, to improve the surgical outcome of subsequent myoma enucleation and to reduce intraoperative blood loss [8, 10].

After an interval of hours or a few days, uterine artery embolization is followed by operative myoma enucleation by laparoscopy or by a transverse or longitudinal incision. The aim of these "hybrid interventions" is to reduce the risk of hysterectomy and substantial intraoperative blood loss requiring subsequent transfusion in women whose uterus is enlarged due to individual or multiple very large myomas, but who explicitly wish to preserve their uterus.

In the following, we present peri- and post-procedural experiences from our own case series (21 patients) and provide an overview of the current international literature on preoperative embolization of patients with myomas.

\section{Methodology}

A retrospective analysis reviewed the data pertaining to 21 consecutive patients who, between January 2011 and March 2016, underwent preoperative uterine artery embolization (PUAE) followed by an open abdominal myoma enucleation. After presenting in a university gynecological outpatient clinic, all patients were informed in detail regarding the various treatment options for large uterus myomatosus. Since the surgeon considered surgery alone without prior embolization to be too risky, all patients with a uterus myomatosus that could be detected at navel height or higher were offered the option of combined treatment using UAE and surgery. For all patients treated in this way, uterine pre- 
servation was a "conditio sine qua non", regardless of an existing desire for children.

The patients were hospitalized and initially received bilateral embolization of the uterine artery (UAE) after probing with a microcatheter. As a rule (20/21) unilateral femoral access was chosen; in one case bilateral access was required due to a contralateral non-accessible outflow of the internal iliac artery. The type of particle used was up to the examining physician: depending on the anatomic situation, microspheres were employed (Embosphere, Meritmedical/Biosphere, Roissy, France) with sizes of $500-700 \mu \mathrm{m}$ or $700-900 \mu \mathrm{m}$; or non-spherical particles (PVA, Contour, BostonScientific, Natick, MA, USA) were selected with sizes of $500-710 \mu \mathrm{m}$. Three patients expressed the desire that resorbable gelatin sponge particles should be used instead of non-degradable embolization particles for their embolization. They felt that the safety, effectiveness, and temporary character of this embolizate were proven and they would not accept nonabsorbable particles [11].

The radiation exposure during the procedure was determined based on the fluoroscopy time and the dose area product using Dose Watch (GE Health Care, Chalfont St. Giles, UK). The patients' effective dose was calculated using XL Dose, Version 2.12 (Stamm et al., Hannover, Germany). All patients received adequate opioidbased pain medication [12].

After 24 to 48 hours post-embolization, the patients underwent a longitudinal incision with the goal of preserving the uterus - Fig. 1.

Between June and August 2016, all 21 patients were surveyed using a mailed questionnaire we developed regarding post-surgical progression, complications, scar length, satisfaction and improvement in symptoms.

For the literature review, in March 2017 we performed a search using Google Scholar, Pubmed and Livivo using the keywords "fibroid”, "myoma”, "preoperative" and "uterine artery embolization” (medical subject heading, MeSH). Those articles providing at least an English or German abstract were considered.

\section{Results}

- Table 1 contains data regarding the patients and the findings of fibroids. The removed fibroids were primarily situated intramurally; some exhibited a broad submucosal component. The UAE was performed without complication on all 21 patients (performed by TK and DS).

The median fluoroscopy time was 11.7 minutes (mean $13.7 \pm 8.72$ minutes), the median effective whole-body dose was $3.49 \mathrm{mSv}$ (mean $9.65 \pm 14.4 \mathrm{mSv}$ ), the median uterine dose was $6.02 \mathrm{mSv}$ (Mean $16.68 \pm 24.48$ ). The mean dose area product was $959.1 \mathrm{cGy}^{*} \mathrm{~cm}^{2}$ (mean $2704 \pm 3935$ cGy*$^{*} \mathrm{~cm}^{2}$ ).

Primary uterus preservation was achieved in all 21 fibroid patients. All interventions were performed by the same surgeon (MD). One patient underwent hysterectomy 14 days postoperatively in another hospital due to heavy vaginal bleeding that could not be otherwise controlled.

A benign leiomyoma was histologically confirmed in all operated women.
None of the 21 planned myoma enucleations required the administration of erythrocyte concentrates (EC) immediately after UAE. With an average blood loss of $475 \mathrm{ml}$ (aspirator contents plus subjective estimate of surgeon based on sponges used, swabs, etc.), there was an average drop in serum hemoglobin from $12.9 \mathrm{~g} / \mathrm{dl}$ preoperatively to $9.5 \mathrm{~g} / \mathrm{dl}$ postoperatively (first and second postoperative day). One patient received a postoperative transfusion of two ECs after hemoglobin declined from $12.6 \mathrm{~g} / \mathrm{dl}$ to $7.3 \mathrm{~g} / \mathrm{dl}$.

The mean hospitalization time of the 21 patients treated with PUAE was 10 days $(8-11)$.

Of the 21 patients, 11 responded to the questionnaire sent to them. The interval between the surgery and patient survey was on average 16 months (10-44). Ten of 11 patients indicated a subjective improvement in symptoms, and 9 would recommend the combined intervention of embolization and surgery. The mean reported duration of postoperative "impairment of daily life" was 42 days (min. 20, max. 98). The mean sick leave reported by the women was 31 days (min. 24, max. 47).

The mean scar length measured by the patients themselves was $12 \mathrm{~cm}$ (mean; min. 10, max. 15). Ten of 11 patients were satisfied with the postoperative result of the incision.

Recurrence of fibroids was reported by 3/11 patients.

Amenorrhea did not occur in any of the queried patients as a result of embolization.

At the time of the survey, one patient was in the second trimester of pregnancy.

\section{Discussion}

The first planned removal of a fibroid was probably performed by Kimball in 1853. By the end of the 19th century, this approach established itself as a standard gynecological-surgical method [13]. Today uterine artery embolization is a world-wide established procedure for treating fibroids as an alternative to surgery. However, the combination of both procedures is still subject to discussion. Embolization as preparation for surgical myoma enucleation was the original intention of Ravina's Paris working group, which was the origin of this transarterial method of fibroid treatment in the early 1990s [14].

According to a study by Unger et al. (2002), hysterectomy patients with a uterine weight of more than $1.000 \mathrm{~g}$ have a significantly increased risk of perioperative complications and the need for blood transfusion [15]. This may also be applicable to interventions during which fibroids of similar weight or volume are removed.

Likewise, the latest common consensus recommendation of German-speaking gynecological and radiological societies holds that uterine artery embolization is only considered in exceptional cases as an option in the context of fertility treatment [16]. This is justified in particular by the possible risk of ovarian damage with subsequent amenorrhea or ovarian dysfunction after embolization.

Guo et al. observed 6 cases amenorrhea (1.23\%) after embolization of 487 patients [17]. Katsumori et al. treated 211 patients and demonstrated an age-related occurrence of amenorrhea. Patients 

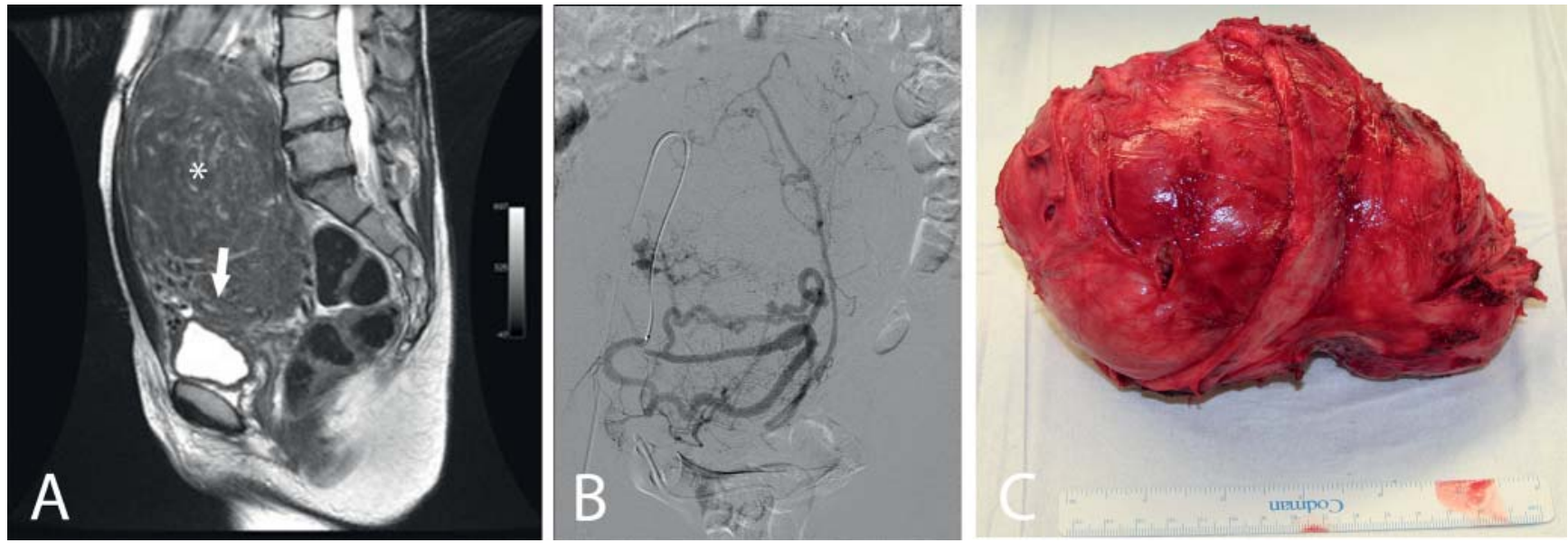

- Fig. 1 shows a T2 weighted MRI scan in sagittal view $\mathbf{A}$ through the pelvis of a 37 year old patient with a very large leiomyoma $\left({ }^{*}\right)$ affecting both the fundus and the dorsal wall of the uterus. The cavity of the uterus (arrow) is very narrow and close to the uterine bladder. 24 hours before fibroid resection transarterial embolization of the uterine arteries was performed $\mathbf{B}$ using spherical particles with a size of $500-700 \mu \mathrm{m}$. The large peritumoral plexus are well depicted. Open resection of the large fibroid $\mathbf{C}$ proceeded without problems without a need to transfusion demanding loss of blood.

- Table 1 Patient characteristics and fibroid data.

patient profile

mean value (standard deviation)

\begin{tabular}{|l|c|}
\hline age (in years) & $42.1(23-52)$ \\
\hline BMI (in $\mathrm{kg} / \mathrm{m}^{2}$ ) & $25.4 \pm 4.7$ \\
\hline $\begin{array}{l}\text { largest diameter of dominant fibroid in } \\
\text { resectate (in } \mathrm{cm} \text { ) }\end{array}$ & $12.7 \pm 3.2$ \\
\hline total weight of removed fibroid (in g) & $1143.3 \pm 615.5$ \\
\hline surgery duration (in min.) & $84.2 \pm 24.3$ \\
\hline intraoperative blood loss (estimated in $\mathrm{ml})$ & $487.5 \pm 306$ \\
\hline hospitalization time (in days) & $10.2 \pm 2.6$ \\
\hline Hb value in g/dl & \\
\hline preoperatively & $12.4 \pm 1.7$ \\
\hline postoperatively & $9.9 \pm 1.4$ \\
\hline
\end{tabular}

who were under 40 years of age at the time of treatment did not report amenorrhoea 6 years after UAE, whereas patients who were older than 45 years at the time of embolization exhibited amenorrhea in $19.7 \%$ of cases 3 years after the procedure [18].

From our point of view, this supports embolization in the context of fertility treatment in patients under 40 years of age.

Therefore, in special cases we also consider a combination of preoperative UAE and subsequent uterus-preserving removal of fibroids as a viable option for women with an explicit desire for children. According to our literature research, between January 2000 and March 2017 three case histories were published $[19-21]$ as well as 8 case series $[8,10,22-27]$ each describing patient cohorts similar to those presented here who were treated with the combined procedure of embolization and myoma surgery. The results of these articles are summarized in $>$ Table 2 .
The literature review demonstrates that preoperative UAE can reduce bleeding complications and that a technically easier removal of fibroid nodes will succeed. The need for blood transfusions especially differed between pre-embolized patients and control groups. Ngeh et al. did not transfuse any patients in the PUAE group, whereas in the group of patients without prior embolization, 3 of 5 patients required administration of 4 to 6 units of erythrocyte concentrates [10]. Üstünsöz et al. did not transfuse any PUAE patient; however, $13 \%$ of non-pre-embolized patients required transfusion [27]. In 2011 Butori et al. confirmed these results [22]; no patients receiving prior embolization required transfusion. The hospitalization time of both groups was the same in these studies.

In the view of the authors, preoperative embolization should be used for those patients who wish to preserve their uterus and for those expected to be at an increased risk of bleeding postoperatively, due to very large and/or multiple fibroids, difficult to remove myomas or those in an unfavorable location. The interval between embolization and surgery is still unclear. In the majority of the comparisons, a time interval of 0 to $24 \mathrm{~h}$ was chosen, only McLucas et al. performed embolization 7 days before myoma enucleation [8]; no difference was found in the results.

In our cohort, uterus preservation was achieved in the majority of cases (90.5\%). A blood transfusion was very rarely necessary, which otherwise would have been expected given the size of the fibroids [10, 15, 23].

The results presented here as well as the data from the literature review show that bleeding complications can be significantly reduced with preoperative UAE. The radiation exposure of $3.49 \mathrm{mSv}$ is reasonable in our view and does not imply a significant malignancy risk, especially against the background of natural radiation exposure in Germany of $2 \mathrm{mSv}$ per year [30]. Three patients with a large or severely convoluted uterus with arteries that were difficult to probe with ultrasound had whole-body dose values of 38,43 and 46 , which explains the 
- Table 2 Preoperative uterine artery embolization in the international literature (only case series, sorted by the year of publication).

\begin{tabular}{|c|c|c|c|c|c|c|}
\hline $\begin{array}{l}\text { first author } \\
\text { publication year }\end{array}$ & $\begin{array}{l}\text { pat. } \\
\text { (n) }\end{array}$ & $\begin{array}{l}\text { control } \\
\text { group }\end{array}$ & $\begin{array}{l}\text { interval between UAE } \\
\text { and surgery (in days) }\end{array}$ & study type & surgical mode (n) & essential results \\
\hline $\begin{array}{l}\text { Ngeh } \\
2004 \text { [10] }\end{array}$ & 5 & yes & n. a. & $\begin{array}{l}\text { prospective } \\
\text { (case control) }\end{array}$ & laparatomy (5) & $\begin{array}{l}\text { blood loss lower in PUAE group; } \\
\text { transfusion only in control } \\
\text { group; fever in } 20 \% \text { vs } 57 \% \text { in } \\
\text { control group; operation time } \\
\text { and duration of hospitalization } \\
\text { similar in both groups }\end{array}$ \\
\hline $\begin{array}{l}\text { Dumousset } \\
2008[22]\end{array}$ & 22 & no & n. a. & retrospective & $\begin{array}{l}\text { laparoscopy (12) } \\
\text { laparatomy (9) } \\
\text { hysterectomy (1) }\end{array}$ & $\begin{array}{l}\text { easier fibroid removal after } \\
\text { PUAE; no blood transfusion; } \\
\text { average Hb value pre-/post- } \\
\text { operative } 12.3 \text { vs } 10.3 \mathrm{~g} / \mathrm{dl}\end{array}$ \\
\hline $\begin{array}{l}\text { Üstünsöz } \\
2007 \text { [26] }\end{array}$ & 15 & yes & 1 & $\begin{array}{l}\text { prospective } \\
\text { (case control) }\end{array}$ & laparatomy (15) & $\begin{array}{l}\text { in group with PUAE Surgery time } \\
\text { shorter; less blood loss; no } \\
\text { transfusion, no hysterectomy }\end{array}$ \\
\hline $\begin{array}{l}\text { Goldman } 2012 \\
\text { [23] }\end{array}$ & 12 & yes & 0.5 & retrospective & laparoscopy & $\begin{array}{l}\text { in PUAE group larger fibroids/ } \\
\text { uteri; less intraoperative blood } \\
\text { loss; longer hospitalization time }\end{array}$ \\
\hline $\begin{array}{l}\text { Malartic } \\
2012[24]\end{array}$ & 12 & no & 0.5 to 2 days & retrospective & $\begin{array}{l}\text { laparoscopy (6) } \\
\text { laparotomy (3) } \\
\text { hysteroscopy (3) }\end{array}$ & $\begin{array}{l}\text { Hb difference pre-/postopera- } \\
\text { tively }-0.97 \mathrm{~g} / \mathrm{dl} \text {; no transfusion; } \\
\text { no serious complications }\end{array}$ \\
\hline $\begin{array}{l}\text { Tixier } \\
2010 \text { [25] }\end{array}$ & 30 & yes & n. a. & retrospective & $\begin{array}{l}\text { laparotomy (25) } \\
\text { laparoscopy (5) }\end{array}$ & $\begin{array}{l}\text { blood loss; surgery time; pre- } \\
\text { postoverative Hb difference in } \\
\text { PUAE compared to control group } \\
\text { lower; hospitalization longer }\end{array}$ \\
\hline $\begin{array}{l}\text { Butori } \\
2011[21]\end{array}$ & 33 & no & $6 h(n=20) / 48 h(n=13)$ & retrospective & $\begin{array}{l}\text { laparotomy (25) } \\
\text { laparoscopy (8) }\end{array}$ & $\begin{array}{l}\text { easier fibroid removal in PUAE } \\
\text { group; no blood transfusion; } \\
\text { average } \mathrm{Hb} \text { value change pre- } / \\
\text { postoperative } 12.9 \text { vs } 11.4 \mathrm{~g} / \mathrm{dl} \text {; } \\
\text { no hysterectomy }\end{array}$ \\
\hline $\begin{array}{l}\text { McLucas } \\
2015[8]\end{array}$ & 20 & no & 7 & retrospective & laparotomy (20) & $\begin{array}{l}\text { no hysterectomy, no transfusion, } \\
\text { no significant postoperative } \\
\text { complications }\end{array}$ \\
\hline
\end{tabular}

wide standard deviation of the indicated mean whole-body dose of $9.65 \pm 14.4 \mathrm{mSv}$. Amenorrhea resulting from embolization was not observed in the treated cohort.

- Fig. 2 shows pedunculated fibroids with a broad base to the uterus. In our case series pedunculated fibroids do not represent a contraindication, since considering current literature, there is no known increased risk of complications of uterine artery embolization due to pedunculated fibroids [28, 29].

Especially in the case of fertility treatment of patients with a myomatous uterus, preoperative uterine artery embolization seems to be a useful therapy option. Due to their altered anatomical situation, these patients have a significant risk of significant fertility limitation and a significantly higher risk of abortion [6, 7], so that surgical restoration of a normal uterine cavity not constricted by fibroid tissue is the objective of treatment. The risk of hysterectomy due to intraoperatively unavoidable bleeding should be reduced as much as possible in women who wish to have children. Furthermore, in the view of the authors, PUAE supports a uteruspreserving procedure even for those patients who refuse blood transfusions, such as Jehovah's Witnesses.

The economic effects of PUAE are difficult to quantify or interpret. The additional expense of embolization itself with a more favorable intra- and postoperative result should take into account partial or complete sparing of blood transfusions and resulting reduced risk of infection as well as high satisfaction on the part of the patient.

Preoperative uterine artery embolization with the goal of retaining the uterus or preserving fertility requires a concerted combination of interventional radiology and gynecology. Well-coordinated interdisciplinary clinical structures and workflows are needed to address these complex cases. 


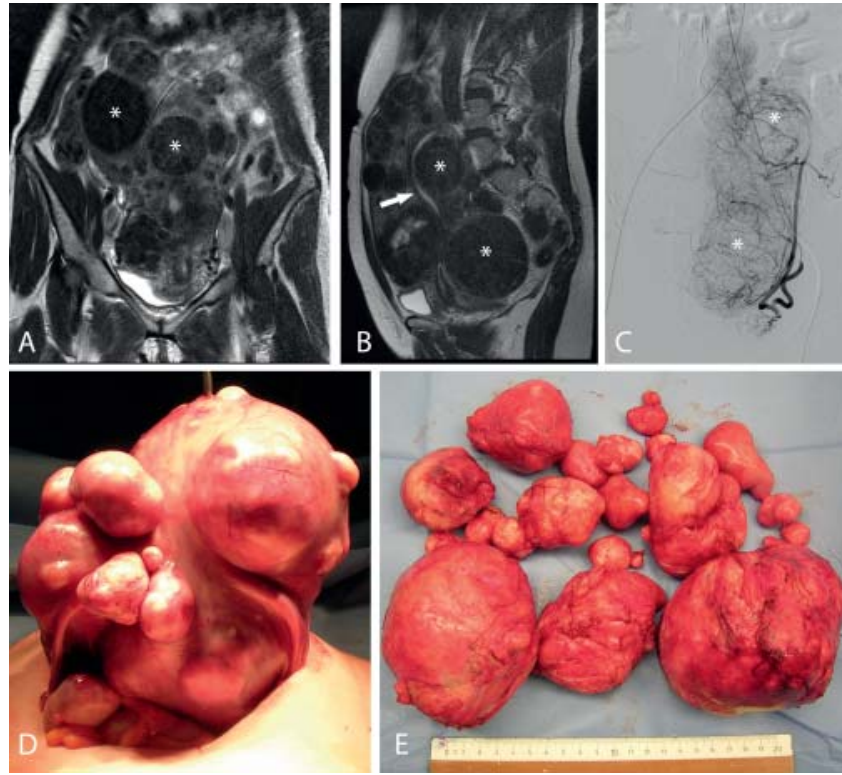

- Fig. 2 shows in A, B the MRI scan of a 42 year old patient with an uterus fully layered with leiomyomas $\left({ }^{*}\right)$. The cavity of the uterus is highly altered and stretched by the multiple fibroids. The patient wanted to get pregnant and due to the number and location of the fibroids a fibroid induced infertility was assumed. C Before operative resection transarterial embolization was performed and the fibroids $\left({ }^{*}\right)$ could be resected during open surgery with only low amount of blood loss $\mathbf{D}, \mathbf{E}$.

\section{Conflict of Interest}

The authors declare that they have no conflict of interest.

\section{References}

[1] Baird DD et al. High cumulative incidence of uterine leiomyoma in black and white women: ultrasound evidence. Am J Obstet Gynecol 2003; 188 : $100-107$

[2] Drayer SM, WH Catherino. Prevalence, morbidity, and current medical management of uterine leiomyomas. Int J Gynaecol Obstet 2015; 131 $117-122$

[3] Della RossaMG et al. Uterine Reconstruction Due to a Giant Myoma. A Case Report and Literature Review. Open Journal of Obstetrics and Gynecology 2016; 6: 64

[4] Gupta S, Jose J, Manyonda I. Clinical presentation of fibroids. Best practice \& research Clinical obstetrics \& gynaecology 2008; 22: 615-626

[5] Borah B] et al. The impact of uterine leiomyomas: a national survey of affected women. American journal of obstetrics and gynecology 2013; 209: 319. e1-319. e20

[6] Klatsky PC et al. Fibroids and reproductive outcomes: a systematic literature review from conception to delivery. American journal of obstetrics and gynecology 2008; 198: 357-366

[7] Parazzini F, Tozzi L et al. Pregnancy outcome and uterine fibroids. Best Practice \& Research Clinical Obstetrics \& Gynaecology 2016; 34: 74- 84

[8] McLucas B, Voorhees WD. The effectiveness of combined abdominal myomectomy and uterine artery embolization. International Journal of Gynecology \& Obstetrics 2015; 130: $241-243$
[9] Ravina J et al. Value of preoperative embolization of uterine fibroma: report of a multicenter series of 31 cases. Contraception, fertilite, sexualite (1992) 1995; 23: 45-49

[10] Ngeh $\mathrm{N}$ et al. Pre-myomectomy uterine artery embolisation minimises operative blood loss. BJOG: An International Journal of Obstetrics \& Gynaecology 2004; 111: 1139-1140

[11] Vilos AG et al. Uterine artery embolization for symptomatic uterine myomas using gelfoam pledgets alone vs embospheres plus gelfoam pledgets: a randomized comparison. Gynecological Surgery 2016; 13: 409-414

[12] Scheurig-Muenkler $C$ et al. Clinical long-term outcome after uterine artery embolization: sustained symptom control and improvement of quality of life. Journal of Vascular and Interventional Radiology 2013; 24: $765-771$

[13] Albrecht H. Die operative Behandlung des Myoms. Geschichtlicher Überblick. In: Biologieund Pathologie des Weibes. Ein Handbuch der Frauenheilkunde und Geburtshilfe, in Die operative Behandlung des Myoms. Geschichtlicher Überblick. In: Biologie und Pathologie des Weibes. Ein Handbuch der Frauenheilkunde und Geburtshilfe, J.H.u.L. Seitz, Editor. Berlin, Wien: Urban \& Schwarzenberg; 1928: 416- 465

[14] Ravina J et al. Arterial embolisation to treat uterine myomata. The Lancet 1995; 346: 671-672

[15] Unger JB, Paul R, Caldito G. Hysterectomy for the massive leiomyomatous uterus. Obstetrics \& Gynecology 2002; 100: 1271 - 1275

[16] Kröncke T, David M. Uterine Artery Embolization (UAE) for fibroid treatment-results of the 6th Radiological Gynecological Expert Meeting. in RöFo-Fortschritte auf dem Gebiet der Röntgenstrahlen und der bildgebenden Verfahren. 2017. ( ) Georg Thieme Verlag KG; 6: 511-514

[17] Guo W et al. Amenorrhea after uterine fibroid embolization: a report of six cases. Ai zheng= Aizheng= Chinese journal of cancer 2008; 27: 1094-1099

[18] Katsumori T et al. Amenorrhea and resumption of menstruation after uterine artery embolization for fibroids. International Journal of Gynecology \& Obstetrics 2008; 103: $217-221$

[19] Nabeshima $\mathrm{H}$ et al. Successful pregnancy after myomectomy using preoperative adjuvant uterine artery embolization. The Tohoku journal of experimental medicine 2003; 200: 145-149

[20] Paxton BE, Lee JM, Kim HS. Treatment of intrauterine and large pedunculated subserosal leiomyomata with sequential uterine artery embolization and myomectomy. Journal of vascular and interventional radiology 2006; 17: 1947-1950

[21] David M, Kröncke T. Preoperative uterine artery embolisation for large uterine fibroids with subsequent uterus preservation-three case histories and review of the literature. Geburtshilfe und Frauenheilkunde 2012; 72: $539-542$

[22] Butori $\mathrm{N}$ et al. Interest of uterine artery embolization with gelatin sponge particles prior to myomectomy for large and/or multiple fibroids. European journal of radiology 2011; 79: 1-6

[23] Dumousset E et al. Preoperative uterine artery embolization (PUAE) before uterine fibroid myomectomy. Cardiovascular and interventional radiology 2008; 31: $514-520$

[24] Goldman KN et al. Uterine artery embolization immediately preceding laparoscopic myomectomy. International Journal of Gynecology \& Obstetrics 2012; 116: 105-108

[25] Malartic C et al. Conservative two-step procedure including uterine artery embolization with embosphere and surgical myomectomy for the treatment of multiple fibroids: Preliminary experience. European journal of radiology 2012; 81: 1-5

[26] Tixier $\mathrm{H}$ et al. Embolisation artérielle utérine par matériel résorbable avant myomectomie. Journal de Radiologie 2008; 89: 1925 - 1929

[27] Üstünsöz B et al. Is uterine artery embolization prior to myomectomy for giant fibroids helpful? Diagnostic and Interventional Radiology 2007; 13: 210 
[28] Smeets AJ et al. Safety and Effectiveness of Uterine Artery Embolization in Patients with Pedunculated Fibroids. Journal of Vascular and Interventional Radiology 20: $1172-1175$

[29] Margau R et al. Outcomes after Uterine Artery Embolization for Pedunculated Subserosal Leiomyomas. Journal of Vascular and Interventional Radiology 2008; 19: 657-661
[30] Strahlenschutz, B.f. 2017. Available from: http://www.bfs.de/DE/themen/ion/umwelt/natuerliche-strahlenbelastung/natuerliche-strahlenbelastung_node.html 